Radosław Skrycki

Uniwersytet Szczeciński

(iD) ORCID: 0000-0002-6710-4774
OBLICZA WOJNY

TOM 4 - MIASTO I WOJNA

tóDŹ 2021 • ISBN 978-83-8220-617-3 • s. 73-96

https://doi.org/10.18778/8220-617-3.05

\title{
POWSTANIE I FUNKCJONOWANIE GARNIZONU W NIEWIELKIM MIEŚCIE PRUSKIM W XVIII WIEKU (STUDIUM KÖNIGSBERGU/CHOJNY WE WSCHODNIEJ BRANDENBURGII)
}

\begin{abstract}
Streszczenie. WXVIII w. państwo pruskie podlegało wielu zmianom, przede wszystkim związanych z nową koncepcją roli państwa w organizacji społeczeństwa, a w ramach państwa - z rolą armii. Podporządkowanie tego pierwszego czynnika sprawom wojskowym spowodowało nowe spojrzenie na organizację wojska, jego zaopatrzenie w rekruta i rozlokowanie w stałych garnizonach w całym kraju. Wojny, prowadzone przede wszystkim przez Fryderyka II, a później przeciwko rewolucyjnej Francji, musiały mieć wsparcie w sprawnie działającym zapleczu. Elementem tego było organizowanie stałych siedzib poszczególnych regimentów, które z czasem stawały się integralną częścią organizmu miejskiego. W artykule omówione zostały uwarunkowania, które legły u podstaw zbudowania i zorganizowania garnizonu w niewielkim mieście wschodniobrandenburskim (Königsberg Nm./Chojna), oraz kolejne zmiany stacjonujących tu regimentów piechoty. Jego ważne strategicznie położenie blisko pomorskiego teatru wojny (III wojna północna), a później śląskiego (trzy wojny śląskie), spowodowało, że przez niemal cały XVIII w. zostało naznaczone obecnością stałego garnizonu. Generowało to pewne napięcia z stosunkach z mieszczanami, nie do uniknięcia w sytuacji, gdy co piąty mieszkaniec miasta był żołnierzem; stworzyło jednak nowe warunki rozwojowe, na co wskazuje niemal podwojenie liczby mieszkańców w ciągu stulecia oraz znaczny przyrost substancji budowlanej.
\end{abstract}

Słowa kluczowe: Prusy w XVIII w., historia armii pruskiej, garnizony w Prusach, historia Chojny, Königsberg 


\section{Reformy wojskowe w Prusach Fryderyka Wilhelma I}

Okres panowania króla Fryderyka Wilhelma I (1688-1740) to czas głębokich reform, także w dziedzinie wojskowości, które na kolejne dziesięciolecia określiły oblicze państwa pruskiego. Wyciągając wnioski z konfliktów ${ }^{1}$, w których brał udział jego ojciec, Fryderyk I (1657-1713), nowy król Prus, panujący w latach 1713-1740, Fryderyk Wilhelm I postanowił dokonać zmian w funkcjonowaniu państwa, podporządkowując wszystkie dziedziny administracji budowie licznej, silnej i sprawnie zarządzanej armii. Zewnętrzną oznaką takiej filozofii było wprowadzenie zwyczaju noszenia munduru przez panującego, co kontynuowali jego następcy, a z czasem przejęli i inni monarchowie. Zatem wraz ze wstąpieniem na tron nowego władcy rozpoczyna się dla Prus okres militaryzacji, obejmujący nie tylko zagadnienia dotyczące funkcjonowania samej armii, ale także innych dziedzin życia, w tym biurokracji, szkolnictwa, religii etc.

Oprócz reform obejmujących uzbrojenie, umundurowanie, skład korpusu oficerskiego czy wreszcie szkolenie i kształcenie oficerów zmiany obejmowały także nową dyslokację poszczególnych pułków (regimentów), ich skoszarowanie i stałe zaopatrzenie w rekruta. Rezonans społeczny, jaki wywołały te działania, oraz ich wpływ na funkcjonowanie aparatu państwowego są stosunkowo dobrze opisane w literaturze historycznej, także w ogólnych opracowaniach o charakterze syntetycznym ${ }^{2}$. Dużo ciekawiej jawi się problem organizacji garnizonów w poszczególnych miejscowościach, szczególnie niewielkich, kwestia budowy

${ }^{1}$ Podwaliny pod zmiany wynikały z doświadczeń wojny o sukcesję hiszpańską, w której Fryderyk I stanął po stronie austriackich Habsburgów i koalicji antyfrancuskiej, a później z wojny północnej na Pomorzu. Wysłanie ponad 30000 żołnierzy na zachodni teatr wojny „ogołociło” kraj z wojska, jednak przyczyniło się do wielu zwycięstw koalicji nad Francuzami. Ostatecznie jednak rozbieżności między koalicjantami spowodowały, że zaangażowanie pruskie zaowocowało jedynie niewielkimi nabytkami terytorialnymi i uznaniem przez kolejne państwa tytułu królewskiego (koronacja w 1701). Po wycofaniu się z walk na zachodzie Europy, energia Prus została skierowana ku zdobyciu nadodrzańskiej części Pomorza (podzielonego w 1653 r. pomiędzy Brandenburgię a Szwecję). Politykę tę kontynuował z sukcesem już następca Fryderyka - Fryderyk Wilhelm I. Vide: O. Hintze, Die Hohenzollern und ihr Werk, Berlin 1915, s. 263 i nast.; A. Kamieński, Polityka zagraniczna Prus 1701-1740, [w:] Prusy w okresie monarchii absolutnej (1701-1806), red. B. WaChow IaK, Poznań 2010, s. 190-209.

${ }^{2}$ Np. Z. Szult Ka, Umocnienie absolutyzmu, narodziny militaryzmu i rozwój pruskiej administracji. Sadownictwo, [w:] Prusy wokresie monarchii..., s. 72-81. 
ich zaplecza bytowego i możliwości uzupełniania stanów osobowych. Integralną częścią tego zagadnienia jest podział państwa na kantony, z których poszczególne jednostki miały zdobywać rekruta ${ }^{3}$. Można postawić tezę, że charakter gospodarczy takiego kantonu mógł wpływać na liczebność regimentu i rodzaj broni, jaki był tam reprezentowany; np. na obszarach z licznymi twierdzami dominowały garnizony forteczne (Śląsk). Inaczej zostały potraktowane formacje „centralne”, takie jak artyleria, zasilane rekrutem z kantonów odległych geograficznie od miejsca stacjonowania, lub korpusy inżynierów, do których powoływano żołnierzy z korpusu oficerskiego, obcokrajowców lub po prostu fachowców w konkretnej dziedzinie.

Wprowadzanie systemu kantonalnego w Prusach rozpoczęto w $1713 \mathrm{r}$. (wstąpienie na tron Fryderyka Wilhelma I), zakończono zaś edyktem z 1 maja 1733 r. ${ }^{4}$ Oznaczał podział kraju na obszary, mające zapewnić stacjonującym na danym terenie jednostkom stały i odpowiednio wysoki dopływ rekruta, przy czym nie pokrywał się dokładnie z podziałem administracyjnym. Popisem objęto chłopców po konfirmacji (a więc od 16. roku życia), nie oznaczało to jednak jednoczesnego wprowadzenia obowiązkowej służby wojskowej. W XVIII stuleciu służba trwała ok. 20 lat, ale w czasie pokoju urlopowano żołnierzy, np. w czasie wzmożonych prac polowych. Chłopców niskich (poniżej 1,65 m) przeznaczano co najwyżej do prac pomocniczych, zaś ze szczególnie rosłych (od 1,88 m) Fryderyk Wilhelm I utworzył gwardię grenadierów, rozwiązaną przez jego syna i następcę - Fryderyka II (1712-1786). Kryterium wzrostu miało znaczenie czysto praktyczne (choć raczej nie dotyczyło to owych grenadierów) - żołnierz musiał mieć odpowiednio duży zasięg ramion, by szybko i bezproblemowo ładować karabin.

Z czasem system kantonalny zaczął obejmować kolejne, zdobywane w toku wojen prowincje (np. Śląsk po I wojnie śląskiej), przy czym ważne z gospodarczego punktu widzenia obszary były z kantonu wyłączane. System ten przetrwał do początków XIX w. (w 1792 r. wprowadzono nowy regulamin, a w 1798 r. - nowy podział) bez większych zmian geograficznych. Owe modyfikacje dotyczyły przede wszystkim zaopatrzenia wspomnianych jednostek „centralnych”,

${ }^{3}$ O. Hintze, op. cit., s. 283-286. Vide: J. Kloosterhuis, >Solide Menage< und >formidable Armeer. Determinanten des preußischen Kantonsystems im 18. Jahrhundert, https://www.hiko-berlin.de/projekte (tu projekt: Die Preußischen Armeekantone; dostęp: 17 XI 2020).

4 A. von Lyncker, Armia pruska 1714-1806, Oświęcim 2012, s. 21. 
zaplecze garnizonów poza Berlinem czy Poczdamem ulegało niewielkim modyfikacjom. Zdarzały się też sytuacje, że kanton zasilał jednostki stacjonujące poza nim (np. dyslokowane lub mające problem z uzupełnieniem stanu we własnym zakresie).

\section{Budowa koszar}

W XVIII w. stopniowo odchodzono od szczególnie uciążliwego dla mieszczan rozmieszczania żołnierzy w prywatnych kwaterach. Musieli oni zapewnić bowiem warunki bytowe odpowiednie do szarży „gościa”, a często wiązało się to z koniecznością wyodrębnienia dodatkowej izby. W nowo budowanych domach musiano więc przewidywać takie rozwiązanie, aby w trakcie kwaterunku wojska w mieście można było bez szkody dla komfortu życia domowników przeznaczyć jeden pokój dla wymuszonego gościa (lub gości). Grzegorz Podruczny zwrócił uwagę, że spowodowało to wykształcenie się charakterystycznego typu budownictwa - domu jedno- lub dwukondygnacyjnego, z izbą żołnierską od strony ulicy5. Dla przykładu: w Chojnie w 1748 r. wojsko rozlokowano aż w 296 domach, czyli niemalże we wszystkich ${ }^{6}$. Leżało zatem w interesie magistratu, by przeznaczyć na cele wojskowe odpowiednie budynki i/lub parcele pod ich wybudowanie, a w interesie garnizonu - skoszarować żołnierzy na możliwie małej przestrzeni, aby zawsze byli pod kontrolą i mogli szybko zostać zwołani.

W Chojnie budowę koszar przeprowadzono w latach 1767-1768, a więc po zakończeniu wojny siedmioletniej, kiedy w całej prowincji rozpoczęły się intensywne prace kolonizacyjne, mające podnieść Nową Marchię i pruskie Pomorze z zapaści demograficznej i gospodarczej. Wojna ciężko doświadczyła prowincję, leżącą między Polską, Pomorzem, Saksonią, Śląskiem i Brandenburgią elektoralną, tu rozegrały się bowiem największe bitwy tego konfliktu: pod Sarbinowem, Kunowicami, Kijami oraz oblężenie Kostrzyna. Sarbinowo i twierdza w Kostrzynie leżały w ówczesnym powiecie chojeńskim, ok. 40-45km

${ }^{5}$ G. Podruczny, Koszary w Chojnie. Zapomniany przyktad XVIII-wiecznej architektury wojskowej, „Rocznik Chojeński” 2015, t. 7, s. 210.

${ }^{6}$ P. Schwartz, Aus dem Ratsprotokollen der Stadt Königsberg, „Die Neumark. Jahrbuch des Vereins für Geschichte der Neumark" 1936, H. 11, s. 55. 


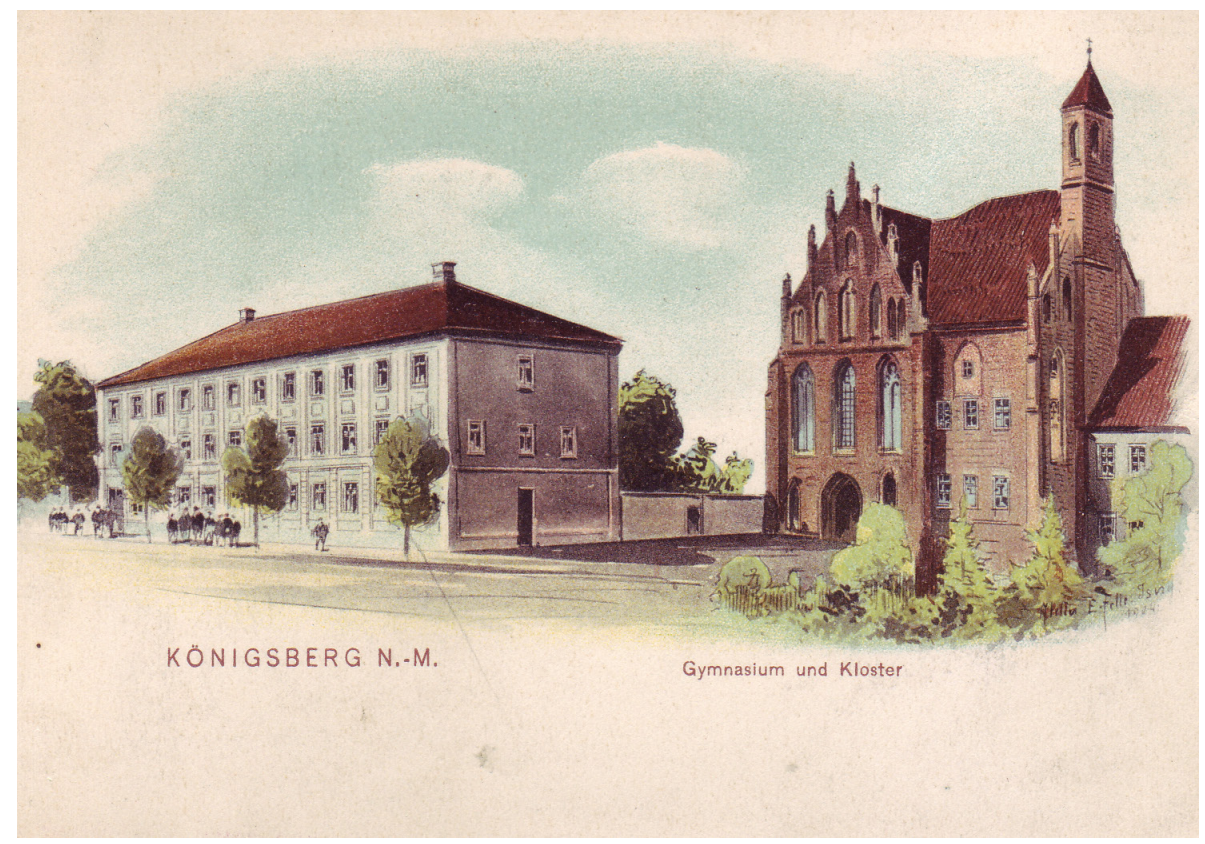

Ryc. 1. „Przedni” budynek koszar na pocztówce z pocz. XX w., obecnie niezachowany (rys. E. Felle, ze zbiorów autora)

na południe od Chojny, w drodze zaś na pole bitwy pod Sarbinowem król Fryderyk II przekraczał Odrę w pobliskich Gozdowicach. Budowa była niezbędna, ponieważ już od samego początku obecności wojska w mieście skarżono się, że nie ma niewystarczającej liczby kwater. W $1721 \mathrm{r}$. na posiedzeniu rady miasta zwrócono na to uwagę, argumentując, że wynika to m.in. z faktu, że żołnierze żenią się w mieście ${ }^{7}$.

Powstały zatem dwa proste budynki (Ryc. 1, 2), zlokalizowane we wschodniej części miasta, w obrębie średniowiecznych murów miejskich i w bezpośrednim sąsiedztwie dawnego klasztoru Augustianów. Taka lokalizacja - intra muros - miała bardzo praktyczne zastosowanie, ograniczała bowiem możliwość dezercji. Koszary umiejscowiono na nieczynnym cmentarzu przyklasztornym. Budulec pozyskano m.in. z rozbiórki okazałych, średniowiecznych przedbrami Bramy Świeckiej i Bramy Barnkowskiej, choć podobno budziło to sprzeciwy

\footnotetext{
${ }^{7}$ Ibidem, s. 51.
} 


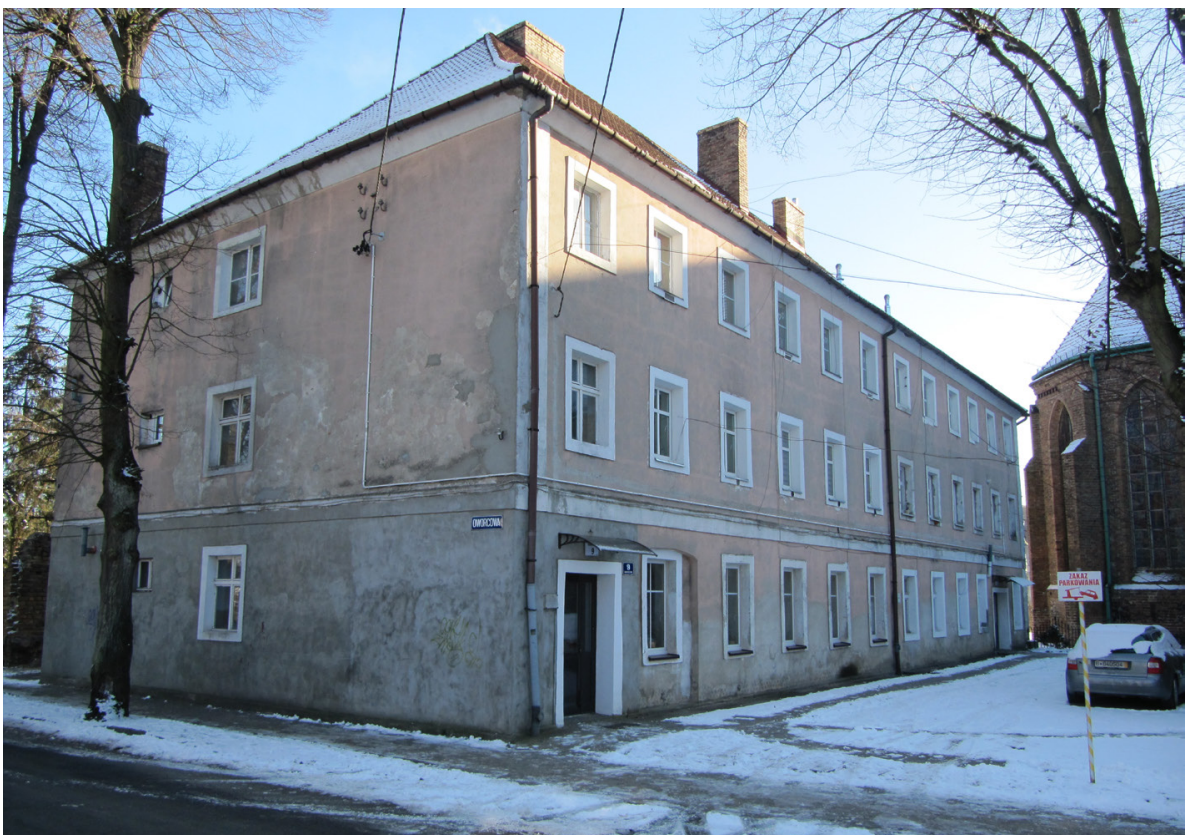

Ryc. 2. Zachowany budynek koszar - stan obecny (fot. Michał Gierke)

mieszczan ${ }^{8}$. Wojsko korzystało także z sąsiednich budynków kompleksu klasztornego: znajdowały się tam magazyny mundurów (Montierungskammer) i budynek (sala?) do ćwiczeń musztry9. Ową mundurownię zlokalizowano w budynkach kościelnych, ponieważ taki obyczaj (ze względów bezpieczeństwa) został wprowadzony przez króla Fryderyka II ${ }^{10}$. W 1782 r. przeniesiono ją do tylnego budynku koszar. W 1791 r. dowódca garnizonu, otrzymawszy wsparcie magistratu i superintendenta, wystąpił do nadrzędnych władz wojskowych z prośbą, aby zlokalizować ją w nowym pomieszczeniu - wytypowano wieżę kościoła Mariackiego, w której podobno było odpowiednio dużo

${ }^{8}$ W. Hoppe, Geschichte der Stadt Königsberg, [w:] Die Kunstdenkmäler des Kreises Königsberg (Neumark), H. II: Die Stadt Königsberg, Berlin b.d., s. 21.

${ }^{9}$ G.F.L. Neumann, Versuch einer Geschichte und Topographie der Stadt Königsberg in der Neumark, Berlin 1824, s. 147.

${ }^{10}$ Mundurownie lokalizowano także na poddaszach ratuszów. Vide: C. JAny, Armia Fryderyka Wielkiego. Od wstąienia Fryderyka Wielkiego na tron do wybuchu wojny siedmioletniej, Oświęcim 2016, s. 312. 
miejsca. Przedłożono nawet dokładny kosztorys prac adaptacyjnych - 74 talary, 19 groszy i 6 fenigów. Wszystko wskazuje na to, że przeniesienie doszło do skutku ${ }^{11}$. Jednak magazyn znajdował się tam nie dłużej niż do 1839 r., wtedy rozpoczęto bowiem prace remontowe w wieży.

W 1799 r., a więc na krótko przed ostateczną likwidacją garnizonu, wzniesiono nowy budynek do ćwiczeń według projektu znanego architekta Davida Gilly'ego, ponieważ stary gmach był w fatalnym stanie i groził zawaleniem (rozebrano go w 1822) ${ }^{12}$. Niestety nie wiadomo, gdzie dokładnie był zlokalizowany, i jak wyglądał. Nieco światła na to drugie zagadnienie mogą rzucać inne realizacje Gilly'ego, m.in. w Berlinie, znane z ikonografii z epoki, choć chojeński był niewątpliwie mniej okazały. Skądinąd wiemy, że już wcześniej w budynku kościoła klasztornego zlokalizowano magazyny, m.in. siana i zboża, z których zapewne korzystało także wojsko. Po likwidacji garnizonu umieszczono w obu budynkach koszarowych szkołę miejską, jednocześnie awansując ją do rangi liceum (od 1817 - gimnazjum), a to dzięki fundacji króla Fryderyka Wilhelma II (1744-1797) z 1791 r., o czym mówiła inskrypcja na elewacji jednego z budynków ${ }^{13}$.

Na planie miasta z ok. 1775 r., na wprost budynków klasztornych, jednak extra muros, widzimy wykreśloną strzelnicę (Schützen Platz), którą być może użytkowało wojsko, a która należała do chojeńskiego bractwa kurkowego ${ }^{14}$. Na miejscu tym aż do końca lat trzydziestych XX w. był też zlokalizowany budynek owego bractwa (Schützenhaus).

Ważny obiekt w strukturze każdego garnizonu stanowił odwach (główna wartownia), któremu towarzyszyły - zapewne w Chojnie również - wartownie w bramach miejskich. $\mathrm{Z}$ reguły lokowano go w najważniejszym (centralnym) miejscu miasta - w okolicach rynku. Były to albo samodzielnie stojące, reprezentacyjne

${ }^{11}$ Brandenburgische Landeshauptarchiv Potsdam, Rep. 33B, nr 817.

12 G. Podruczny, op. cit., s. 212. Ze złego stanu tego budynku zdawano sobie sprawę przynajmniej od 1746 r., wtedy też mówiono o wykorzystaniu elementów murów miejskich do budowy nowych pomieszczeń. Vide: P. SCHWARTz, op. cit., s. 53.

13 P. Schwa RTZ, Das Schulwesen der Stadt Königsberg in der Neumark, von der ältesten Zeit bis zur Stiftung des Gimasiums 1817, Königsberg Nm. b.d. Tłumaczenie inskrypcji przytacza G. PoDRUCZNY (op. cit., s. 210, przyp. 23).

${ }_{14}$ Wielkoformatowa reprodukcja mapy i jej charakterystyka vide: R. Skrycki, Plan Chojny z 1631 roku oraz mapa okolic miasta z II potowy XVIII wieku, „Rocznik Chojeński” 2019, t. 10, s. 160-168. 


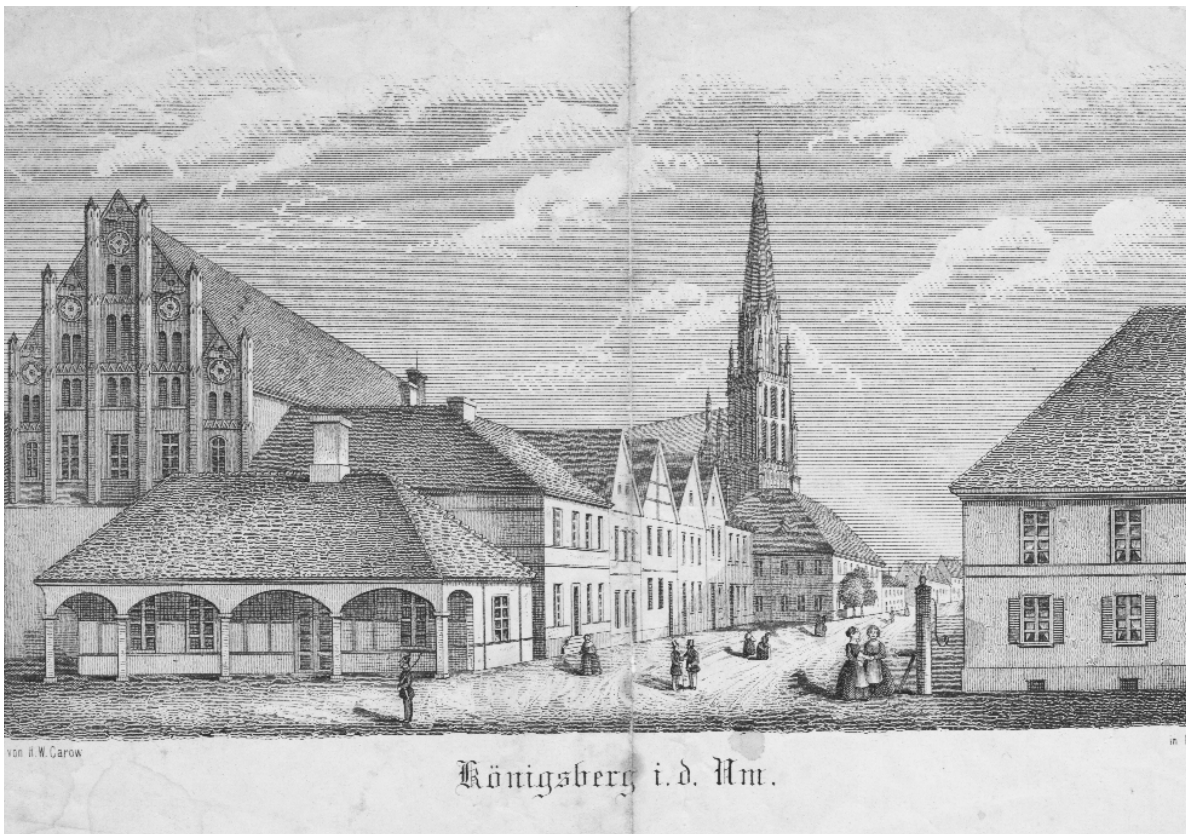

Ryc. 3. Chojeński odwach na litografii H.W. Carowa, ok. 1840 (ze zbiorów autora)

budynki, albo - w skrajnych przypadkach - podcieniowe budowle, zwykle dobudowywane do gmachów użyteczności publicznej ${ }^{15}$. W Chojnie mamy do czynienia z tą drugą sytuacją. Mimo stosunkowo licznego garnizonu odwach został zlokalizowany na tyłach ratusza i miał formę niskiego, podcieniowego budynku z czterospadowym dachem, „przytulonego” do większej bryły gmachu magistratu. Podcień był tyleż prostą, co skuteczną konstrukcją: chronił żołnierzy przed warunkami atmosferycznymi, a jednocześnie pozwalał na swobodną i niezakłóconą obserwację okolicy. Choć umieszczony na tyłach ratusza i rynku, był jednocześnie zlokalizowany przy ważnym skrzyżowaniu głównych ulic, łączących wszystkie trzy miejskie bramy. Nie wiadomo, kiedy powstał i jak długo pełnił swoją funkcję. $\mathrm{Na}$ fotografiach z końca XIX w. już nie istnieje, natomiast jedyny przekaz ikonograficzny, jakim dysponujemy, to niedatowana litografia, wydana dwukrotnie w Chojnie ok. 1840 r. (Ryc. 3). W tym czasie odwach mógł pełnić także funkcje policyjne, na co wskazuje postać żołnierza stojącego przed budynkiem.

15 G. Podruczny, op. cit., s. 211. 


\section{Kolejne jednostki stacjonujące w Chojnie i ich kanton}

Wszystkie stacjonujące w Chojnie pułki (regimenty) były formacjami pieszymi. Ich stan liczebny był różny. Według Willy’ego Hoppe w 1728 r., a więc w czasie, gdy stacjonowały tu oddziały 19 Pułku, liczba żołnierzy (nie wliczając oficerów) wynosiła 520 na 2119 mieszkańców-cywilów, zaś na przełomie XVIII i XIX w., u schyłku funkcjonowania garnizonu, stosunek ludności „cywilnej” do „wojskowej” wynosił w przybliżeniu 4,3:1 (na 3995 mieszkańców przypadało 746 wojskowych) ${ }^{16}$. Zatem proporcje przez niemal całe stulecie były podobne, co mogłoby wskazywać, że stosunek liczbowy kwaterujących żołnierzy do ludności cywilnej, nawet w miastach koszarowych, mógł być odgórnie ustalany. Oczywiście zależał przede wszystkim od wielkości miasta i jego potencjału gospodarczego, a wynosił mniej więcej 1:4.

Pierwszą stacjonującą regularnie w Chojnie jednostką był 19 Pułk Piechoty von Braunschweig ${ }^{17}$, którym w czasie stacjonowania dowodził margrabia Albrecht brandenburski (od 1702 do 1731) a później margrabia Karol brandenburski (w latach 1731-1763) ${ }^{18}$. Regiment został utworzony w 1702 r. w Duisburgu z przeznaczeniem dla armii holenderskiej, angażującej się w hiszpańską wojnę sukcesyjną. W $1715 \mathrm{r}$. widzimy już jednak pułk pod Stralsundem na pomorskim teatrze wojennym (III wojna północna), a w czasie wojen śląskich i wojny siedmioletniej walczył on w Czechach, Saksonii i Nowej Marchii (m.in. pod Małujowicami, Pragą, Lutynią i Kunowicami, by wymienić tylko największe z bitew). Po I rozbiorze Polski i wybuchu powstania kościuszkowskiego jednostki pułku były obecne w Polsce; rozwiązano go w listopadzie 1806 r., miesiąc po klęsce armii pruskiej pod Jeną i Auerstädt.

Do Chojny regiment przybył w 1714 r. w sile dwóch kompanii (a więc ok. 250 żołnierzy z oficerami) ${ }^{19}$, przy czym rozlokowany był także w innych

${ }^{16}$ Dane na 1801 r. za: F.W.A. von Bratring, Statistisch-Topographische Beschreibung der gesamten Mark Brandenburg, Bd. 3: Neumark, Berlin 1809.

17 Oprócz numerów pułki pruskie otrzymywały nazwę od aktualnego dowódcy, zatem w okresie stacjonowania w Chojnie 19 Pułk Piechoty nosił nazwę „Margrabia Albrecht”, a później - „Margrabia Karol”. W przypadku, gdy dowódcy dwóch jednostek mieli to samo nazwisko, pułk starszego wiekiem opisywano dodając do nazwiska „Alt”, młodszego - „Jung”. W artykule przyjęto nazewnictwo za A. von Lynckerem (Armia pruska 1714-1806, Oświęcim 2012).

18 A. von LyNCKer, op. cit., s. 74.

19 Vide: G. Gieraths, Die Kampfhandlungen die Brandenburgisch-Preussischen Armee 1626 - 1807, Berlin 1964, s. 68. R. SchміD (Von der ehemaligen Garnison Königsberg Nm., „Königsberger Kreikalender” 1931, s. 139) podaje, że owe dwie kompanie pułku przybyły już w 1711 r. Należy 


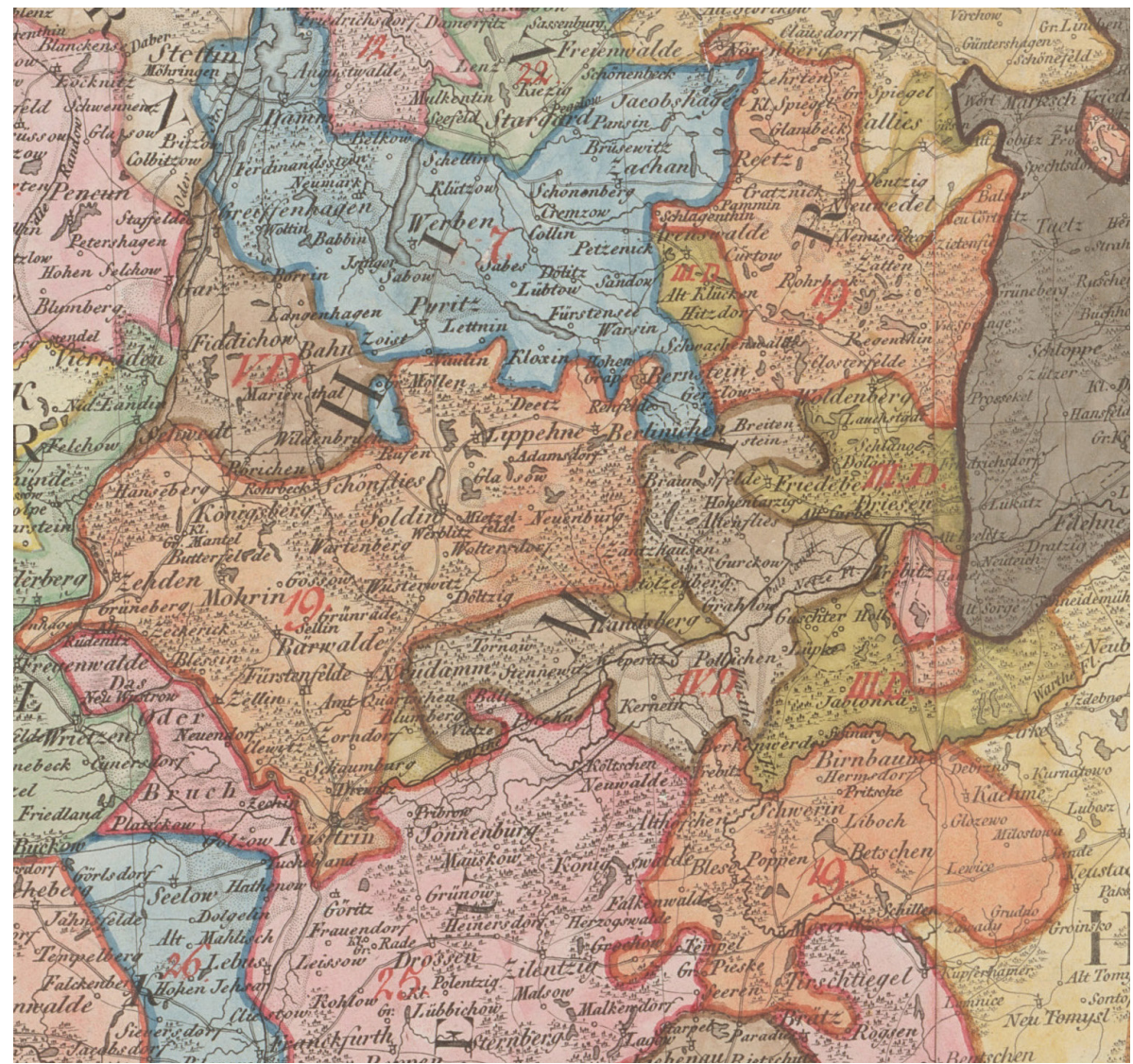

Ryc. 4. Wycinek mapy północnych Niemiec Gottholda; kanton chojeńskiego garnizonu oznaczony liczbą 19 (źródło: Staatsbibliothek zu Berlin, SBB IIIC Kart. U 15195)

miastach nowomarchijskich (m.in. Gorzów Wielkopolski, Strzelce Krajeńskie, Myślibórz) oraz we Frankfurcie nad Odrą. Poza krótkim epizodem wojny na Pomorzu, podczas której pułk oblegał (skutecznie) Stralsund oraz walczył na Rugii, nieprzerwanie do 1737 r. stacjonował w mieście ${ }^{20}$.

jednak tę informację odrzucić, ponieważ w tym roku i następnym pułk przebywał w okolicach Bouchain we Francji, przy granicy z Belgią. Także w pierwszej monografii dotyczącej historii pułku (do końca wojny siedmioletniej) wskazano, że z Niderlandów (tj. granicy francusko-belgijskiej) odwołano go w 1713 r., vide: Vollständige Geschichte aller königlichen preussischen Regimenter..., cz. 2: No. XIX Geschichte und Nachrichten von den königl. preuß. Infranterie Regimente Prinz Friedrich August von Braunschweig..., Halle 1763, s. 4; tutaj także pełny szlak bojowy pułku oraz jego dowódcy.

${ }^{20}$ A. von Lyncker, op. cit., s. 75; G. Gieraths, op. cit., s. 68. 
Kanton pułku można dość precyzyjnie określić według mapy północnych Niemiec, sporządzonej przez H.H. Gottholda, wydanej w Berlinie w $1811 \mathrm{r}^{21}$ Mapa posłużyła jako podkładowa dla zilustrowania sytuacji podziału królestwa pruskiego na kantony w XVIII w. Tak więc kanton należący do 19 Pułku Piechoty - tu opisanego nazwiskiem przedostatniego dowódcy - Karla Ludwiga Bogislava von Götze (1743-1806), dowodzącego od 1794 r. - został opatrzony liczbą 19 i obejmował:

- w powiecie chojeńskim: Chojnę, Moryń, Cedynię, Mieszkowice i Kostrzyn

- w powiecie myśliborskim: Myślibórz, Lipiany i Barlinek

- w powiecie choszczeńskim: Recz i Drawno

- fragment Wielkopolski z Międzychodem, Skwierzyną, Międzyrzeczem i Zbąszynem (Ryc. 4).

Biorąc pod uwagę, że w podziale kantonalnym zachodziły niewielkie zmiany, mapę tę można uznać za przedstawiającą zasięg kantonu garnizonu chojeńskiego przez cały okres jego funkcjonowania, niezależnie od regimentu, który aktualnie w mieście stacjonował.

Sztandar pułku w okresie fryderycjańskim był ciemnoczerwony z białym krzyżem maltańskim (margrabia Karol, dowódca w latach 1731-1763, był wielkim mistrzem zakonu joannitów baliwatu brandenburskiego), czarnym orłem oraz sentencją: „Pro Gloria et Patria”. Po 1763 r. uległ modyfikacji. W tym samym czasie umundurowanie stanowiły niebieska kurtka z czerwonymi mankietami, kamizelka i żółte spodnie (Ryc. 5).

W 1718 r. na krótko do Chojny przybył nowo sformowany 5 Pułk Dragonów Królowej pod dowództwem generała-porucznika Achaza von der Schulenburga (1669-1731). Jego pobyt w mieście wiązał się z relokacją z Halberstadt i Dornburga w kierunku właśnie przejmowanego przez Prusy Pomorza, już w następnym roku pułk został przeniesiony doSchwedt nad Odrą, a od 1721 r. (czyliw rok po oficjalnym przejęciu od Szwedów Szczecina ze znaczną częścią Pomorza na zachód od Odry) także na Pomorze pruskie (m.in. Pasewalk, Goleniów, Dąbie i Wolin) ${ }^{22}$.

${ }^{21}$ Frenkreichs Vergrösserung durch das bisherige Königreich Holland und das nordwestliche Deutschland getheilt in XII Departements nebst dem angrenzenden Königreich Westphalen, Staatsbibliothek zu Berlin (dalej: SBB) IIIC Kart. U 15195.

22 A. von LynCKer, op. cit., s. 277; A. Bierca (Historia jednostek wojskowych garnizonu Chojna XVIII-XIX wieku. Część 1: wiek XVIII, „Rocznik Chojeński” 2009, t. 1, s. 63) mylnie podaje, że był 
Po odejściu w 1736 r. 19 Pułku miasto przez siedem lat było wolne od kwaterunku. W 1743 r. Chojna stała się głównym garnizonem 39 Pułku Piechoty, który został sformowany trzy lata wcześniej w Templin i Myśliborzu (to drugie miasto obok Chojny będzie także główną siedzibą regimentu ${ }^{23}$. Pułk był najdłużej stacjonującą w mieście jednostką, ponieważ miał tu swoją siedzibę przez niemal pięćdziesiąt lat. Kwestią ciekawą pozostaje data opuszczenia miasta. Alexander von Lyncker oraz Günther Gieraths wskazują Chojnę jako miejsce kwaterunku jeszcze w 1791 r. Tymczasem od 1790 r. zmienia się kanton regimentu (wcześniej zapewne pokrywał się z kantonem 19 Pułku), i teraz obejmuje okolice Gniezna, Bydgoszczy i Inow rocławia. Wydaje się zatem, że po wymarszu na Śląsk (kwiecień - październik 1790) pułk już do miasta nie wrócił i został oficjalnie relokowany do Wielkopolski. Od 1792 r. brał udział w wojnie przeciwko Francji, oficjalnie stacjonował w Poznaniu, a w 1806 r. został rozwiązany.

Podczas stacjonowania w Chojnie na czele regimentu stali członkowie książęcej rodziny von Braunschweig: w latach 1743-1744 - książę Ferdynand von Braunschweig (1721-1792); w latach 1744-1745 książę Albrecht von Braunschweig (młodszy brat Ferdynanda, 1725-1745), w latach 1745-176324 książę Fryderyk Franciszek von Braunschweig (1732-1758; najmłodszy brat dwóch poprzednich) ${ }^{25}$. W 1763 r. (według Lynckera: do 1771) na czele pułku stanął książę Wilhelm Adolf von Braunschweig (1745-1770), wydaje się jednak, że przynajmniej w ostatnim roku był tylko nominalnym dowódcą, ponieważ w 1770 r. zaciągnął się do służby rosyjskiej, gdzie zmarł podczas kampanii przeciwko Turcji.

to pierwszy pułk w mieście i błędnie określa jego numer jako 3. W rzeczywistości 3 Pułk Dragonów stacjonował w pobliskim Trzcińsku-Zdroju.

23 A. von Lyncker, op. cit., s. 121-123; G. Gieraths, op. cit., s. 126. Z protokołów posiedzeń rady miasta wynika jednak, że nowy garnizon przybył lub miał przybyć do miasta już w końcu października 1740 r.; mowa także o konieczności pobielenia izb dla oficerów. Vide: P. SCHWARTZ, Aus dem Ratsprotokollen der Stadt Königsberg 1728-40, „Schriften des Vereins für Geschichte der Neumark" 1908, H. 21, s. 265.

${ }^{24}$ Takie daty podaje A. von LyNCKeR (op. cit., s. 121). Zwraca uwagę fakt, że książę zginął pięć lat wcześniej w bitwie z Austriakami pod Hochkirch. Wynika z tego, że przez ten okres, przynajmniej oficjalnie, stanowisko dowódcy nie było obsadzone.

${ }^{25} \mathrm{Na}$ wieży kościoła Mariackiego w Chojnie zachowała się z tego okresu tablica epitafijna dla dziewczynki zmarłej w wieku „1 roku 10 miesięcy 15 dni” - Henrietty Sophii Louisy von Wientersheim (1749-1751). Z rozbudowanej inskrypcji wiemy, że była córką ówczesnego dowódcy chojeńskiego garnizonu (w randze pułkownika, w latach 1743-1752), Leopolda Friedricha Ludwiga von Wintersheima (1701-1761). Ów pułkownik zajmował w mieście dwa domy, za które płacił 90 talarów czynszu rocznie, vide: P. SchWARTZ, Aus dem Ratsprotokollen der Stadt Königsberg, s. 53. 


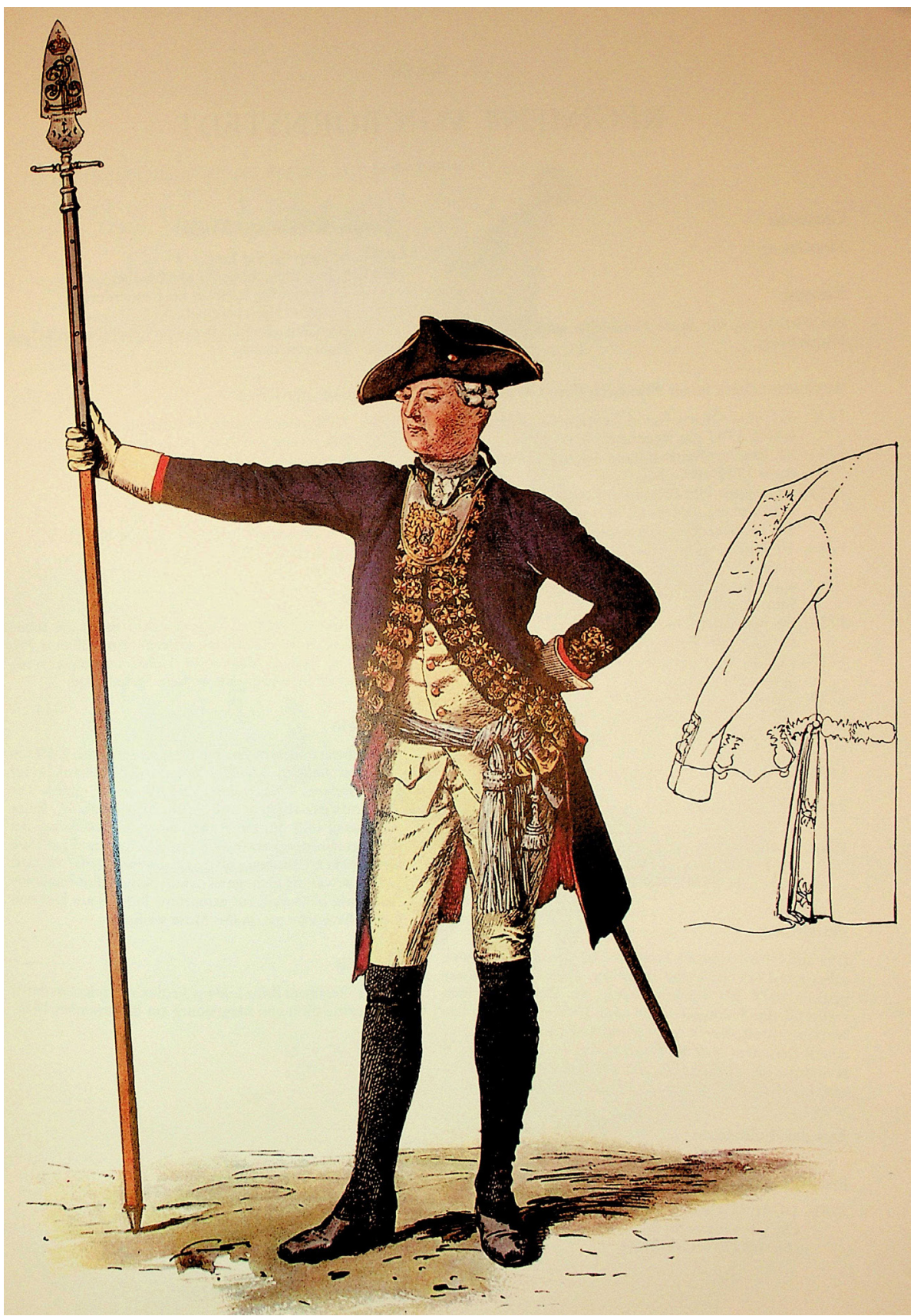

Ryc. 5. Oficer 19 Pułku Piechoty z okresu stacjonowania w Chojnie (źródło: A.F.E. von Menzel, Die Armee Friedrichs des Grossen in ihrer Uniformierung, gezeichnet und erläutert von Adolph Menzel. Eine Auswahl von 100 Tafeln in mehrfarbiger Faksimile-Reproduktion herausgegeben von F. Skarbina, C. Jany, Berlin 1908, reprint: Augsburg 2005) 
Był on ostatnim dowódcą z rodu Braunschweigów; w tym czasie regiment nosił nazwę Jung-Braunschweig.

Po „epoce” Braunschweigów w latach 1771-1783 pułkiem dowodził Wichard von Möllendorf (1724-1816), pełniący jednocześnie funkcję inspektora piechoty na Pomorzu. Ostatnim „chojeńskim” dowódcą regimentu (1783-1793) był Christian Ludwig von Kenitz (Könitz, 1724-1797). Gdy Kenitz odchodził na emeryturę, pułk walczył z Francją (m.in. oblegał Moguncję), a jego następcą został ppłk (oberstleutnant) Daniel von Crousaz (1746-1811).

To właśnie 39 Pułk miał największy wpływ na oblicze miasta, ponieważ to dla niego wybudowano miejskie koszary (w latach 1768-1769, o czym mowa wyżej). Przez tak długi okres stał się integralną częścią organizmu miejskiego. Zlokalizowany po I wojnie śląskiej i zajęciu niemal całego Śląska przez Prusaków, ze strategicznego punktu widzenia podnosił znaczenie Chojny jako miasta leżącego w bezpośrednim zapleczu granicy z nową prowincją.

Umundurowanie (Ryc. 6) to niebieska kurtka, mankiety, kamizelka i spodnie - żółte. Sztandar pułkowy żółty z czterema ukośnymi, białymi klinami oraz lecącym na tle słońca orłem i dewizą: „Pro Gloria et Patria”.

W 1791 r., podczaskampanii przeciwko Francji, regiment na cztery lata został zastąpiony w Chojnie batalionem rezerwowym przeniesionym tu z Gdańska.

Być może ze szkoleniem garnizonu w terenie wiąże się ciekawe, kartograficzne źródło przechowywane w berlińskiej Bibliotece Państwowej ${ }^{26}$. Jest to niedatowana (ok. 1770?), rękopiśmienna mapa przedstawiająca obszar na zachód od Chojny, między miejscowościami Mętno, Krzymów i Stoki. Z sytuacji topograficznej przedstawiono przede wszystkim wzniesienia, cieki wodne, drogi, charakterystyczne punkty w miejscowościach, przy czym same wsie zostały zaprezentowane bardzo niedokładnie i schematycznie. Liczne i zalesione wzniesienia na tym terenie (kreślone za pomocą szrafowania) zostały zaopatrzone w sygnatury ziemnych fortyfikacji polowych (redany?), z zaznaczonymi trajektoriami ostrzału przedpola. Pomiędzy nimi oznaczone są ustawienia manewrującej piechoty. W niektórych przypadkach przy umocnieniach podano liczbę załogi: od 100 do 150 ludzi, a zatem obsadzenie wszystkich przekraczałoby znacznie możliwości żołnierzy stacjonujących tylko w Chojnie. Plan więc mógł dotyczyć manewrów całego regimentu lub nawet kilku, które co jakiś czas ordynował król

\footnotetext{
${ }^{26}$ Project zum Lager bey Rhedorff und Hansberg ohnweid Königsberg, SBB IIIC Kart. N 6296.
} 


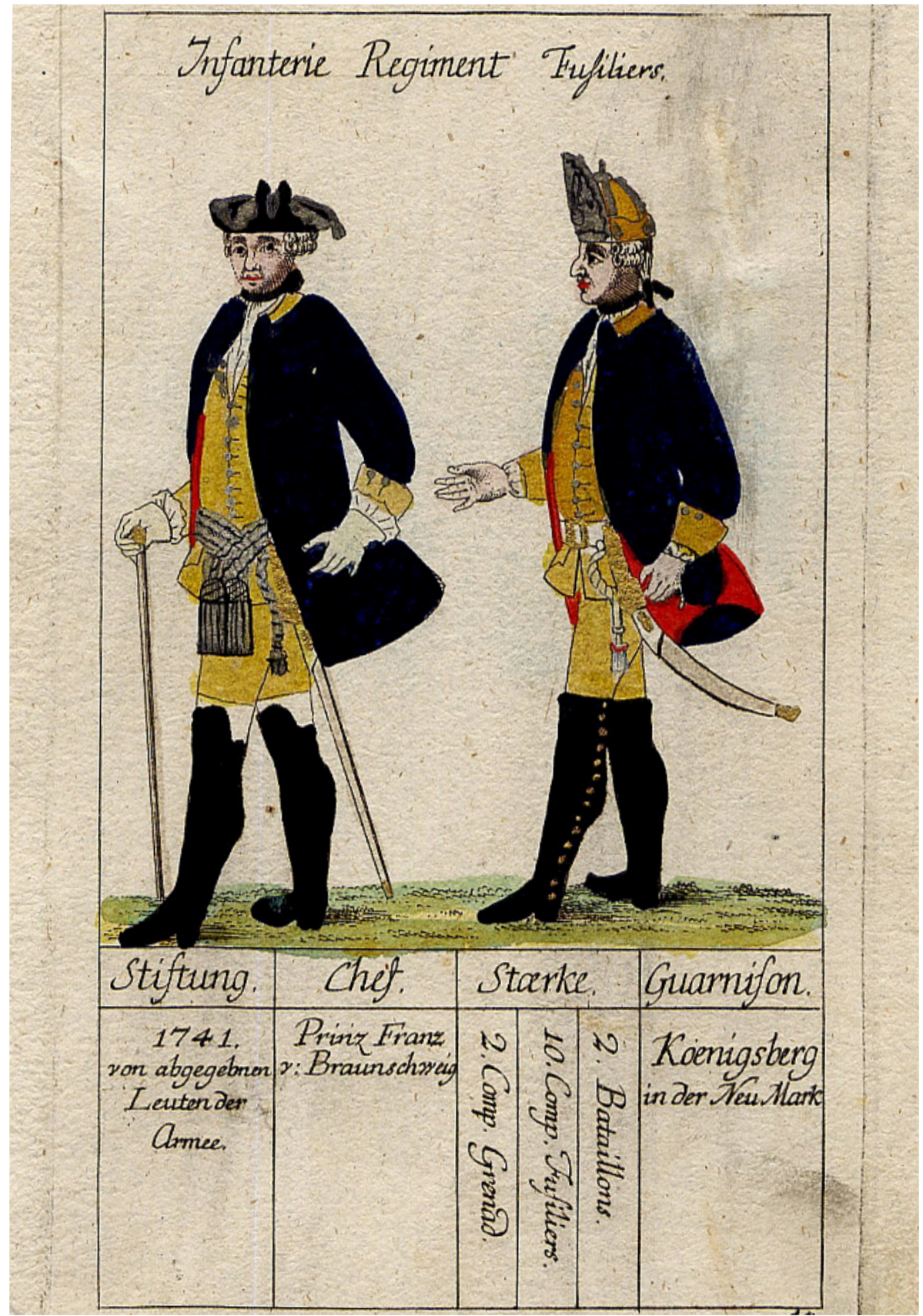

Ryc. 6. Żołnierz 39 Pułku Piechoty, stacjonujący w Chojnie, z okresu dowództwa F. von Braunschweiga (miedzioryt prawdopodobnie G.N. Raspego, ok. 1760; ze zbiorów autora) 
Fryderyk ${ }^{27}$. Jeżeli interpretacja jest poprawna, daje to nam pojęcie, w jaki sposób przebiegało w warunkach pokoju szkolenie wojska (kładziono nacisk na współdziałanie całego regimentu, nie tylko poszczególnych batalionów), i na jakie elementy zwracano szczególną uwagę (walka ze wsparciem umocnień polowych i przeciwko nim, manewrowanie w trudnym geograficznie terenie). Podział na bataliony został oznaczony kolorem, a ponieważ nie zróżnicowano sygnatur poszczególnych rodzajów broni, wydaje się, że plan dotyczy tylko piechoty i jej artylerii organicznej.

Ostatnim regimentem stacjonującym w Chojnie w okresie staropruskim był 35 Pułk Piechoty Prinz Heinrich von Preussen. Po wycofaniu batalionu zapasowego 39 Pułku, od 1795 r. Chojna (obok Pyrzyc i Myśliborza; w tym ostatnim mieście stacjonowali grenadierzy) była jego główną siedzibą ${ }^{28}$. Pułk przebywał tu do momentu rozwiązania w 1806 r. Ponieważ został powołany po wstąpieniu na tron Fryderyka II (1740) dla jego młodszego brata księcia Henryka Pruskiego (1726-1802) z kompanii przybocznej 6 Regimentu Królewskiego, jego kanton początkowo pokrywał się z kantonem królewskim, by w okresie stacjonowania w Chojnie obejmować część Wielkopolski: Wolsztyn, Nowy Tomyśl, Pniewy, Wronki, Oborniki, Chodzież, Łobżenicę. Zwolniono zatem dawny kanton chojeński z kwaterunku, mimo że na jego terenie nie stacjonował już żaden inny regiment ${ }^{29}$. I mimo tego, że wyprowadzony stąd 39 Pułk miał także kanton w Wielkopolsce, zbliżony zasięgiem do pułku 35. Oznacza to zatem, że po III rozbiorze Polski ciężar utrzymania jednostek pruskich spadł na nowo pozyskane obszary, odciążając jednocześnie ziemie „starych” Prus, intensywnie rozwijających się po zniszczeniach wojny siedmioletniej.

Przez cały okres istnienia pułku na jego czele stał książę Henryk. Regiment walczył w czasie wojen śląskich na Śląsku i w Czechach (brał udział m.in. w bitwie pod Kunowicami) oraz przeciwko Francji, w tym m.in. w słynnej bitwie

${ }^{27}$ Były to np. „ataki na szańce” lub manewrowanie masami wojska w polu, vide: C. JANY, op. cit., s. 124.

28 A. von Lyncker, op. cit., s. 112-113; G. Gieraths, op. cit., s. 114; A. von Dertzen, Die Garnison Königsberg Nm. 1740 - 1870, „Königsberger Kreis-Kalender” 1927, s. 75; C. JANY, op. cit., s. 14. A. BierCA (op. cit., s. 69-70) - znowu błędnie - podaje zupełnie inny numer Pułku (18) oraz innych dowódców. 18 Pułk stacjonował w Berlinie i Poczdamie.

29 Owo „odciążenie” nie było do końca zupełnym zwolnieniem powiatu chojeńskiego ze świadczeń na rzecz wojska. W latach 1764-1806 ludny i dość duży powiat chojeński zaopatrywał także berliński 25 Pułk Piechoty (z części nadodrzańskiej). A. von LynCker, op. cit., s. 91. 


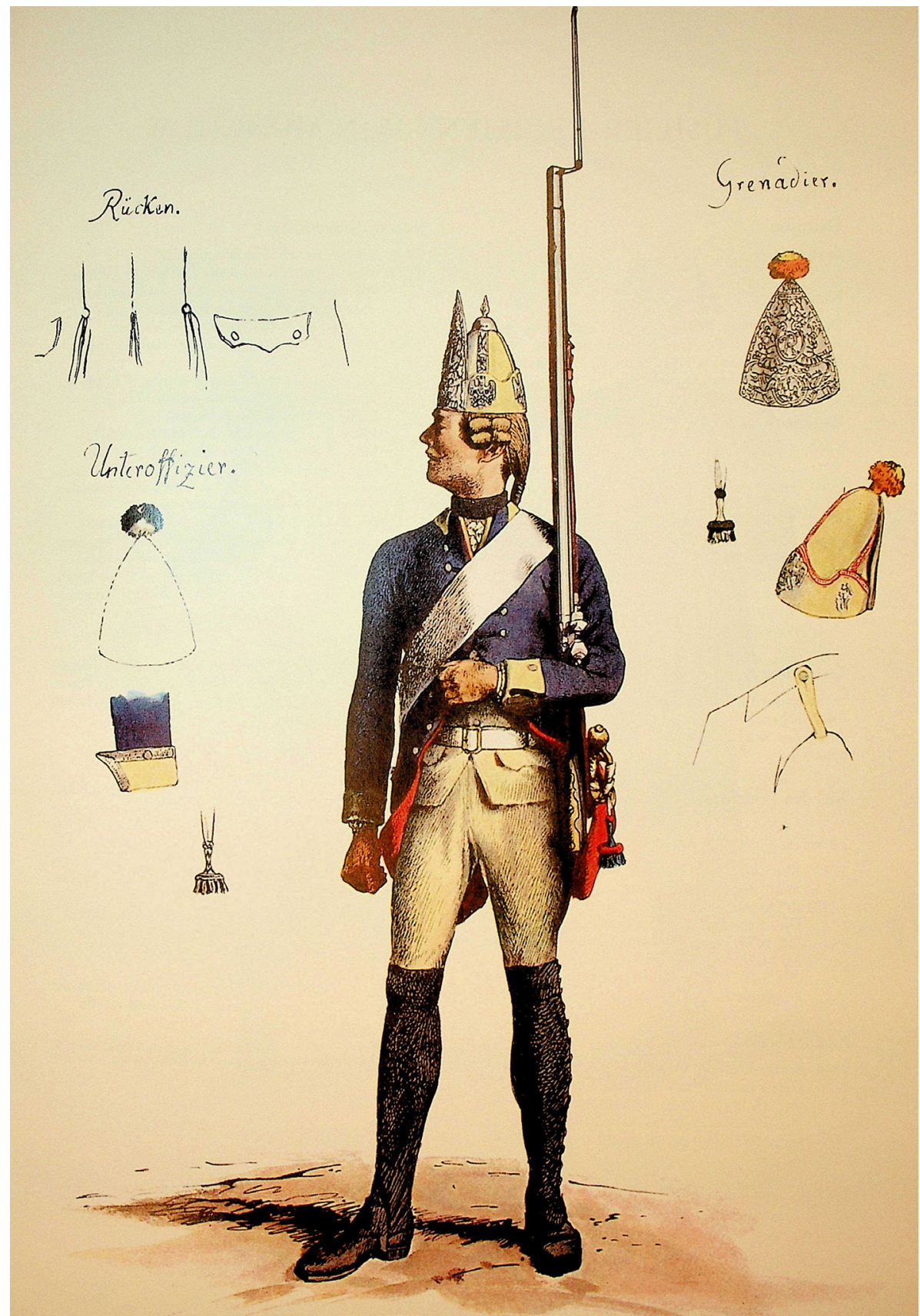

Ryc. 7. Fizylier 35 Pułku Piechoty z okresu fryderycjańskiego (źródło: A.F.E. von Menzel, Die Armee Friedrichs des Grossen in ihrer Uniformierung, gezeichnet und erläutert von Adolph Menzel. Eine Auswahl von 100 Tafeln in mehrfarbiger Faksimile-Reproduktion herausgegeben von F. Skarbina, C. Jany, Berlin 1908, reprint: Augsburg 2005) 
pod Auerstädt (1806). W momencie rozwiązania część jednostki przebywała w twierdzy w pobliskim Kostrzynie. W ten sposób kończy się historia garnizonu chojeńskiego w okresie staropruskim.

Umundurowanie podobne jak w przypadku 39 Pułku: niebieska kurtka, mankiety, kamizelka i spodnie - żółte (Ryc. 7). Sztandar jasnożółty z orłem w locie na tle słońca i standardową dewizą: „Pro Gloria et Patria”.

Nieco światła na obustronne stosunki garnizonu i miasta rzucają opublikowane przez Paula Schwartza protokoły rady miejskiej z lat $1728-1740^{30}$ oraz ich wybór obejmujący materiały do $1749 \mathrm{r} .^{31}$

Rysuje nam się tu kilka pól wzajemnego oddziaływania, z których wiele wynika z nieprzystosowania miasta do przyjęcia na stałe znacznej liczby wojska oraz z tarć między społecznością mieszczańską a oficerami, reprezentującymi powagę majestatu królewskiego. Problemem były niewątpliwie przymusowe pobory, których dokonywała armia Fryderyka Wilhelma I, a które zaczęły się wraz z przybyciem wojska do miasta. Wydaje się, że mogły mieć one miejsce przed uporządkowaniem problemu rekrutacji za pomocą systemu kantonalnego; np. już w maju 1715 r. pewien rolnik z Barnkowa (wówczas wieś, obecnie dzielnica miasta) skarżył się radzie, że jakiś oficer zabrał mu dwóch synów do wojska ${ }^{32}$.

Osobnym zagadnieniem są też nadużycia żołnierzy i konflikty z mieszkańcami. Dla przykładu: w lipcu 1728 r. pewien żołnierz wszedł w spór z miejskim woźnym, który niezasadnie go o coś oskarżył, przez co nieszczęsny wojak został wychłostany publicznie w twierdzy w Oranienburgu. Ponieważ obaj trwali przy swoim, rada postanowiła ukarać obu. Woźny, za prywatną zemstę, miał odsiedzieć trzy dni i trzy noce w lochu o chlebie i wodzie, zaś żołnierz miał zapłacić dwadzieścia talarów kaucji i w ciągu sześciu tygodni dowieść swojej niewinności ${ }^{33}$. Niestety, o przyczynie sporu źródło milczy.

\footnotetext{
30 P. Schwa RTZ, Aus dem Ratsprotokollen der Stadt Königsberg 1728-40.

${ }^{31}$ Ibidem, s. 5-56.

${ }^{32}$ P. Schwa RTZ, Aus dem Ratsprotokollen der Stadt Königsberg, s. 47.

${ }_{33}$ Ibidem, s. 252.
} 
Czasami dochodziło do rękoczynów, jak wtedy, gdy burmistrz Daue zranił żołnierza szpadą, bo podobno ten był zadłużony i ubliżał magistratowi; a w ogóle burmistrz nie wiedział, że ma do czynienia z żołnierzem. Ponieważ na ten konflikt nałożyła się agresja tegoż chojeńskiego rajcy wobec córki niejakiego Hischfelda, nałożono na niego karę dziesięciu talarów ${ }^{34}$.

Jednak stosunek miasta do żołnierzy nie był wyłącznie negatywny. Trzeba pamiętać, że wojsko było przedmiotem szczególnego zainteresowania i troski kolejnych królów pruskich, a wola królewska dla poddanych była prawem. Opieką otaczano zatem inwalidów wojskowych oraz zdemobilizowanych żołnierzy. Toteż jesienią $1734 \mathrm{r}$. miasto wynajęło pewnemu rezerwiście izbę w ratuszu („z tyłu po prawej stronie”) za osiem talarów czynszu rocznie, z zastrzeżeniem, że nie będzie mógł tam trzymać psa, ale za to będzie miał dostęp do piwa ${ }^{35}$. Na jakich zasadach i w jakiej ilości - tego, niestety, nie wiemy.

Co prawda, bezpośrednio nie wiążą się one z obecnością garnizonu w mieście, ale niewątpliwie uciążliwe były przemarsze wojsk, szczególnie w czasie wojny północnej, której teatr wojenny zaczynał się kilka kilometrów na północ od Chojny, oraz późniejszej wojny siedmioletniej. W kwietniu 1715 r. przez miasto przemaszerowały wojska saskie, w czerwcu przybyło 200 jeńców heskich, natomiast w lipcu 1717 r. odnotowano przemarsz dziesięciu batalionów Rosjan ${ }^{36}$. Wreszcie u zarania wojny siedmioletniej, w lipcu 1740 r. przez miasto przejeżdżał nowo koronowany król Fryderyk II, co przecież także musiało wiązać się z odpowiednimi przygotowaniami ${ }^{37}$.

Miasto miało obowiązek wyposażać wojsko w produkty codziennej potrzeby; powracający z II wojny śląskiej batalion musiał zostać zaopatrzony w słomę do spania, prześcieradła i poduszki ${ }^{38}$. Dwa lata później dowódca, przywołany wyżej płk Wintersheim, wystąpił z żądaniem do władz miasta o wydanie nowych sienników ${ }^{39}$. Zresztą oczekiwania pułkownika były dużo dalej idące:

${ }^{34}$ Ibidem, s. 265.

${ }^{35}$ Ibidem, s. 261.

${ }^{36}$ Ibidem, s. 47, 49. Obecność Saksończyków i jeńców wiązać należy z zajęciem Szczecina w 1713; Rosjanie wracali z kampanii przeciwko Szwedom w Meklemburgii.

37 P. Schwartz, Aus dem Ratsprotokollen der Stadt Königsberg 1728-40, s. 264.

${ }_{38}$ P. SCHWARTZ, Aus dem Ratsprotokollen der Stadt Königsberg, s. 53.

${ }^{39}$ Ibidem, s. 55. 
w grudniu 1749 r. zażądał od mieszczan gruntownego oczyszczenia wszystkich ulic ${ }^{40}$. Ta ciekawa i lakoniczna informacja wiele mówi o stanie sanitarnym miasta.

Jednak od czasu do czasu pojawiają się w protokołach informacje o zaopatrzeniu garnizonu również w środki wojenne. Tak więc np. 19 sierpnia $1745 \mathrm{r}$. do miasta przybył transport broni dla 39 Pułku: 300 karabinów, 150 funtów (ok. $70 \mathrm{~kg}$ ) prochu oraz $4500 \mathrm{kul} \mathrm{karabinowych}^{41}$. Wydaje się, że zamówienie zostało opłacone przez chojeńskich mieszczan, informacja o nim pojawia się bowiem w protokole posiedzenia rady, a w styczniu 1746 r., wobec podpisania pokoju w Dreźnie po II wojnie śląskiej (25 grudnia 1745), dokonano podsumowania: Chojna „zużyła” całość z owych 150 funtów prochu, a dodatkowo 226 skałek do karabinów ${ }^{42}$.

XVIII stulecie dla wielu niedużych miast pruskich było okresem mocnego ich naznaczenia pełnioną funkcją miasta garnizonowego. Wraz z rozwojem armii pruskiej, a także administracji, odgrywającej rolę służebną wobec potrzeb wojskowych, ten militarny charakter mógł stać się gorsetem hamującym rozwój przestrzenny miasta (przede wszystkim w miastach-twierdzach), lecz jednak dawał też bodziec do podniesienia ekonomicznego z długotrwałych skutków wojny trzydziestoletniej czy późniejszych wojen Brandenburgii ze Szwecją. Armia - poza tym, że wymagała kwaterunku, a więc zapewnienia podstawowych potrzeb bytowych i szkoleniowych - była także wypłacalnym nabywcą wytworów rzemiosła, rolnictwa, w pewnym stopniu także nośnikiem wzorców kultury (oficerowie), szczególnie istotnym w niewielkich miasteczkach. $\mathrm{Z}$ tą drugą sytuacją mamy do czynienia w Chojnie; wskazuje na to chociażby intensywna i nowoczesna rozbudowa miasta w całym okresie pełnienia funkcji miasta garnizonowego i znaczny przyrost liczby mieszkańców w ciągu tego stulecia. Tak więc w 1719 r. w Chojnie było tylko 281 domów krytych dachówką i aż 49 opuszczonych parceli. Do końca stulecia liczba domów z dachówką

\footnotetext{
40 Ibidem, s. 56.

41 Ibidem, s. 52.

42 Ibidem, s. 53.
} 
podwoiła się, liczba pustek spadła zaś prawie o połowę $e^{43}$. Nie są to może liczby oszałamiające, pokazują jednak systematyczny rozwój małego, prowincjonalnego miasta w dobie wojen i wielkich przemian społeczno-politycznych w kraju.

Szczególnego znaczenia garnizony nabrały w okresie fryderycjańskim. Król, rządzący Prusami od 1740 r., zreorganizował armię, rozwiązując część pułków, i w ich miejsce powołując nowe, jednocześnie powiększając stan armii o $1 / 5^{44}$. Prowadząc wojny (z przerwami) przez połowę swego panowania, musiał podporządkować administrację i życie państwa sprawom wojny. Ulga nastąpiła wraz z zagarnięciem ziem polskich, na które przeniesiono ciężar utrzymania części jednostek. Jednak po dziesięciu latach dwie klęski pod Jeną i Auerstädt zakończyły staropruski okres w dziejach kraju i jego armii, stawiając nowe wyzwania i konieczność modernizacji, w tym sposobu myślenia o wojsku, kraju i jego gospodarce. Prusy lekcję tę niewątpliwie odrobiły.

\section{BIBLIOGRAFIA}

\section{Źródła archiwalne}

\section{Brandenburgische Landeshauptarchiv Potsdam}

Rep. 33B nr 817.

\section{Staatsbibliothek zu Berlin}

IIIC Kart. N 6296, U 15195.

\section{Źródła drukowane}

Bratring F.W.A. von, Statistisch-Topographische Beschreibung der gesamten Mark Brandenburg, Bd. 3: Neumark, Berlin 1809.

Neumann G.F.L., Versuch einer Geschichte und Topographie der Stadt Königsberg in der Neumark, Berlin 1824.

43 F.W.A. BRATRING, op. cit., s. 98.

${ }^{44}$ C. JANY, op. cit., s. 18. 
Schwartz P., Aus dem Ratsprotokollen der Stadt Königsberg 1728-40, „Schriften des Vereins für Geschichte der Neumark” 1908, H. 21.

Schwartz P., Aus dem Ratsprotokollen der Stadt Königsberg, „Die Neumark. Jahrbuch des Vereins für Geschichte der Neumark" 1936, H. 11.

Vollständige Geschichte allerköniglichen preussischen Regimenter..., cz. 2: No. XIX Geschichte und Nachrichten von den königl. preuß. Infranterie Regimente Prinz Friedrich August von Braunschweig..., Halle 1763.

\section{Literatura}

Bierca A., Historia jednostek wojskowych garnizonu Chojna XVIII-XIX wieku. Część 1: wiek XVIII, „Rocznik Chojeński” 2009, t. 1, s. 63-73.

Dertzen A. von, Die Garnison Königsberg Nm. 1740-1870, „Königsberger Kreis-Kalender” 1927 , s. 74-76.

Gieraths G., Die Kampfhandlungen die Brandenburgisch-Preussischen Armee 1626-1807, Berlin 1964.

Hintze O., Die Hohenzollern und ihr Werk, Berlin 1915.

Hoppe W., Geschichte der Stadt Königsberg, [w:] Die Kunstdenkmäler des Kreises Königsberg (Neumark), H. II, Die Stadt Königsberg, Berlin b.d., s. XIII-XXXVIII.

Jany C., Armia Fryderyka Wielkiego. Od wstapienia Fryderyka Wielkiego na tron do wybuchu wojny siedmioletniej, Oświęcim 2016.

Kamieński A., Polityka zagraniczna Prus 1701-1740, [w:] Prusy w okresie monarchii absolutnej (1701-1806), red. B. Wachowiak, Poznań 2010, s. 190-232.

Lyncker A. von, Armia pruska 1714-1806, Oświęcim 2012.

Podruczny G., Koszary w Chojnie. Zapomniany przyktad XVIII-wiecznej architektury wojskowej, „Rocznik Chojeński” 2015, t. 7, s. 205-215.

Schmidt R., Von der ehemaligen Garnison Königsberg Nm., „Königsberger Kreikalender” 1931.

Schwartz P., Das Schulwesen der Stadt Königsberg in der Neumark, von der ältesten Zeit bis zur Stiftung des Gimasiums 1817, Königsberg Nm. b.d.

Skrycki R., Plan Chojny z 1631 roku oraz mapa okolic miasta z II potowy XVIII wieku, „Rocznik Chojeński” 2019, t. 10, s. 157-168.

Szultka Z., Umocnienie absolutyzmu, narodziny militaryzmu i rozwój pruskiej administracji. Sadownictwo, [w:] Prusy w okresie monarchii absolutnej (1701-1806), red. B. Wachowiak, Poznań 2010, s. 65-132. 


\section{Netografia}

Kloosterhuis J., > Solide Menage $<$ und >formidable Armee . Determinanten des preußischen Kantonsystems im 18. Jahrhundert, https://www.hiko-berlin.de/projekte (dostęp: 17 XI 2020).

\section{Radosław Skrycki}

\section{THE ESTABLISHMENT AND FUNCTIONING OF THE GARRISON IN A PRUSSIAN SMALL TOWN IN THE XVIII CENTURY (KÖNIGSBERG/CHOJNA IN EAST BRANDENBURG STUDY)}

Summary. In the 18th century, the Prussian State was undergoing a number of changes, most importantly related to the new conception of the role of the state in the social organisation and the role of the army within the state. The subordination of this first factor to the military matters caused a new vision of the army organisation, its recruitment and the disposition in fixed garrisons throughout the country. The wars, waged primarily by Frederic II, and later against a revolutionary France, had to be supported by an efficiently operating hinterland. Its element was the organization of fixed seats of regiments, that over time became an integral part of the urban organism.

In the article, conditionings were discussed which laid at the roots of creating and organizing the garrison in a small city in the Eastern Brandenburg and subsequent alternations of stationed there regiments of the infantry. It's important strategical positioning, close to the Pomeranian theatre of war (3rd Northern War), and later the Silesian one (three Silesian Wars) caused, that for an almost entire 18th century it was marked with the presence of a fixed garrison. This caused certain tensions with the townspeople, inevitable in a situation when every fifth man in town was a soldier; however, it created new development opportunities, which is indicated by almost the duplication of the population within a century and the considerable increase of the number of buildings.

Keywords: Prussia in 18th Century, Prussian army, garrisons in Prussia, history of Chojna 